\title{
Multiple resistance to bacterial halo blight and bacterial leaf spot in Coffea spp.*
}

\author{
Resistência múltipla à mancha aureolada e \\ à mancha foliar bacteriana em Coffea spp.
}

\author{
Lucas Mateus Rivero Rodrigues ${ }^{1,2 * *}$ (D), Suzete Aparecida Lanza Destéfano ${ }^{2,3}$ (D), \\ Irene Maria Gatti de Almeida ${ }^{3 * * *}$, Luís Otávio Saggion Beriam ${ }^{3}$ (D), \\ Masako Toma Braghini ${ }^{1}$ (D), Oliveiro Guerreiro Filho ${ }^{1,4}$
}

\begin{abstract}
Breeding for genetic resistance is an important method of crop disease management, due to the numerous benefits and low cost of establishment. In this study, progenies of 11 Coffea species and 16 wild C. arabica accessions were tested for their response to Pseudomonas syringae pv. garcae, the causal agent of bacterial halo blight, a widespread disease in the main coffee-producing regions of Brazil and considered a limiting factor for cultivation in pathogen-favorable areas; and also to $P$. syringae pv. tabaci, causal agent of bacterial leaf spot, a highly aggressive disease recently detected in Brazil. Separate experiments for each disease were carried out in a greenhouse, with artificial pathogen inoculations and ideal moisture conditions for disease development. The results showed that C. canephora, C. congensis, C. eugenioides, C. stenophylla, and C. salvatrix progenies, the wild $C$. arabica accessions Dilla \& Alghe and Palido Viridis, and cultivar IPR 102 contain satisfactory levels of simultaneous resistance against bacterial halo blight and bacterial leaf spot. These results are useful in breeding programs for durable resistance to multiple biotic agents, providing new combinations of resistance alleles by hybridization, as well as for phytopathological studies, to identify infraspecific variability of the pathogens.
\end{abstract}

KEYWORDS: germplasm bank; resistant accessions; Pseudomonas syringae pv. garcae; Pseudomonas syringae pv. tabaci.
RESUMO: O melhoramento de plantas para resistência genética é um método importante para o manejo de doenças, pelos inúmeros benefícios e baixo custo de implementaçáo. No presente estudo, progênies de 11 espécies de Coffea e 16 acessos selvagens de C. arabica foram testados quanto à resposta a Pseudomonas syringae pv. garcae, agente causal da mancha aureolada, doença disseminada nas principais regióes produtoras de café do Brasil e considerada fator limitante para o cultivo em áreas favoráveis a patógenos; e também para P. syringae pv. tabaci, agente causal da mancha foliar bacteriana, doença altamente agressiva detectada recentemente no Brasil. Experimentos separados para cada doença foram realizados em estufa, por meio da inoculação artificial dos patógenos em condiçôes ideais de umidade para o desenvolvimento das doenças. Os resultados mostraram que as progênies Coffea canephora, C. congensis, C. engenioides, $C$. stenophylla e $C$. salvatrix, além dos acessos selvagens de C. arabica Dilla \& Alghe e Palido Viridis e da cultivar IPR 102, possuem níveis satisfatórios de resistência simultânea contra mancha aureolada e mancha foliar bacteriana. Os resultados descritos são úteis em programas de melhoramento para resistência duradoura a múltiplos agentes bióticos, fornecendo novas combinaçôes de alelos de resistência por hibridização, bem como para estudos fitopatológicos, para identificar a variabilidade infraespecífica dos patógenos.

PALAVRAS-CHAVE: banco de germoplasma; acessos resistentes; Pseudomonas syringae pv. garcae; P. syringae pv. tabaci.

'Centro de Café Alcides Carvalho, Instituto Agronômico - Campinas (SP), Brazil

${ }^{2}$ Fellowship from Coordenação de Aperfeiçoamento de Pessoal de Nível Superior - Brasília (DF), Brazil ${ }^{3}$ Instituto Biológico - Campinas (SP), Brazil

${ }^{4}$ Fellowship from Conselho Nacional de Desenvolvimento Científico e Tecnológico - Brasília (DF), Brazil

*This paper is part of the doctoral thesis of the first author.

**Corresponding author: lucasmriverorodrigues@gmail.com

*** in memoriam.

Received on: 05/18/2018. Accepted on: 07/01/2019 


\section{INTRODUCTION}

The current taxonomy of the genus Coffea comprises 125 species (KRISHNAN et al., 2015), but only grains of $C$. arabica Lineu and C. canephora Pierre ex A. Froehner species are commercially exploited, corresponding to 55 and $45 \%$, respectively, of the world production (USDA, 2014). According to DAVIS et al. (2006), C. liberica Bull. ex Hiern can also be cited, although commercially it plays a marginal role.

In spite of the wide diversity of the genus, few species have been used in breeding programs of $C$. arabica and C. canephora, partly because of the genetic barriers that hamper the development of hybrid plants (CARVALHO et al., 1984), but mainly due to the difficulty in reestablishing the original genome of the cultivated varieties and, consequently, the selection of a stable cultivar.

Some species such as $C$. eugenioides S. Moore (NAGAI et al., 2008), C. liberica (BETTENCOURT; CARVALHO, 1968; FORTUNATO et al., 2010), and C. racemosa Lour. (GUERREIRO FILHO, 2007), respectively, were already used as allele donor parents of genes related to caffeine synthesis, resistance to leaf rust Hemileia vastatrix Berkeley \& Broome and resistance to coffee leaf miner Leucoptera coffeella Guérin-Ménéville.

For an improved use of Coffea species in breeding programs, mainly for tolerance to abiotic stresses and resistance to biotic stresses such as diseases and pests, traits of agronomical interest must be phenotyped. In fact, the Coffea germplasm banks were primarily phenotyped for the main diseases of the crop. Some of these diseases have become relevant in a number of coffee-producing countries and sources of pathogen resistance can still be found in wild genetic resources preserved in in situ collections.

Bacterial halo blight of coffee (BHB), caused by Pseudomonas syringae pv. garcae (AMARAL et al., 1956; YOUNG et al., 1978), can cause large-scale damage and disease outbreaks, according to COSTA et al. (1957). Outbreaks of the disease occur in areas with high inoculum potential or in nurseries, making coffee production and/or the sale of seedlings infeasible. In Brazil, BHB has already been detected in several regions of the states of São Paulo, Paraná and Minas Gerais (AMARAL et al., 1956; KIMURA et al., 1973; ZOCCOLI et al., 2011; RODRIGUES et al., 2017b). Moreover, ALMEIDA et al. (2012) reported an increase in disease incidence and severity in the main coffee-producing states of Brazil.

In the African continent, BHB has already been described in Kenya, Ethiopia and Uganda (RAMOS; SHAVDIA, 1976; KOROBKO; WONDIMIGEGNE 1997), and in Asia, only in China (XUEHUI et al., 2013).

Resistance sources to BHB were identified in C. stenophylla G. Don and C. eugenioides accessions of the germplasm bank of the Agronomic Institute of Paraná (Instituto Agronômico do Paraná - IAPAR) (MOHAN et al., 1978). Exotic varieties of C. arabica, e.g., Dilla \& Alghe, Geisha, Harar, and S. 12 Kaffa (MORAES et al., 1975), Ennarea and Semierecta (MOHAN et al., 1978), SL 28 (KAIRU, 1997), as well as 38 wild accessions from Ethiopia, mentioned in a Food and Agriculture Organization (FAO) survey of 1968 (FAO, 1968; MOHAN et al., 1978), were resistant to P. syringae pv. garcae. In addition, plants of $C$. canephora, $C$. congensis and C. liberica var. dewevrei species proved susceptible to this pathogen (COSTA et al., 1957).

In Brazil, all arabica cultivars registered by the Brazilian Ministry of Agriculture, Livestock and Food Supply (Ministério da Agricultura, Pecuária e Abastecimento - MAPA) are BHBsusceptible, except for cultivar IPR 102, which is resistant to the disease (SERA et al., 2017).

Bacterial leaf spot (BLS), caused by $P$. syringae pv. tabaci (WOLF; FOSTER, 1917) (YOUNG et al., 1978) is a lessknown disease, firstly observed in a coffee seedling nursery in southern São Paulo State (DESTÉFANO et al., 2010). A recent study reported the occurrence of BLS under field conditions in the state of Paraná, in separated and mixed infections with P. syringae pv. garcae (RODRIGUES et al., 2017b). To date, BLS has been poorly studied, probably because its symptoms are easily confused with $\mathrm{BHB}$, for being extremely similar.

In addition, no source of BLS resistance was described. The commercial $C$. arabica cultivars Mundo Novo, IAC 125 RN, Obatã IAC 1669-20, Obatã IAC 4739, Bourbon Amarelo, and Icatu Vermelho IAC 4045, as well as a genotype of Timor Hybrid IAC 1559-13 and cultivar Apoatá IAC 2258 of $C$. canephora, were found to be susceptible to this pathogen (RODRIGUES et al., 2009).

Unlike P. syringae pv. garcae, which is specific to coffee trees (KIMURA et al., 1973), P. syringae pv. tabaci naturally infects a wide range of hosts (BRADBURY, 1986; MALAVOLTA JUNIOR et al., 2008), which represent a source of primary inoculum for coffee plants.

In view of the epidemiological importance of BLS for coffee cultivation, the knowledge about resistance sources to this pathogen must be deepened, and useful information for breeding programs of the crop obtained, targeting the introgression of genes responsible for the expression of resistance to biotic agents in susceptible commercial cultivars.

The purpose of this study was to identify simultaneous resistance sources to BHB and BLS in Coffea spp., as well as in C. arabica accessions of the Germplasm Bank of the Agronomic Institute of Campinas (Instituto Agronômico de Campinas IAC), Campinas, São Paulo, Brazil, which are potentially useful in breeding programs, especially for $C$. arabica.

\section{MATERIALS AND METHODS}

\section{Germplasm accessions}

Seeds of 11 species of the genus Coffea and 16 accessions of C. arabica (Tables 1 and 2), in the Coffea Germplasm Bank 
of the IAC, were transplanted at the cotyledonary stage into $180-\mathrm{cm}^{3}$ tubes containing plant substrate and Osmocote ${ }^{\circledR}$ fertilizer $\left(3 \mathrm{~g}\right.$. $\left.\mathrm{L}^{-1}\right)$, and maintained in a greenhouse until the evaluation of BHB and BLS severity.

\section{Bacterial strains and inoculation}

The bacterial strains used in the experiments were obtained from the Phytobacteria Culture Collection of the Biological Institute (Coleção de Culturas de Fitobactérias do Instituto

Table 1. Frequency of resistance, moderately resistance and susceptible plants, according to the disease rating scale ( 0 - 5 points) in Coffea spp., in response to infection by Pseudomonas syringae pv. garcae, causal agent of bacterial halo blight, evaluated in 2012 and 2013 , and against $P$. syringae pv. tabaci, causal agent of bacterial leaf spot, evaluated in 2015.

\begin{tabular}{|c|c|c|c|c|c|c|c|c|c|c|c|c|c|c|c|c|c|c|c|c|c|}
\hline \multirow{4}{*}{ Germplasm } & \multicolumn{7}{|c|}{ E1 - 2012} & \multicolumn{7}{|c|}{ E2 - 2013} & \multicolumn{7}{|c|}{ E3 - 2015} \\
\hline & \multicolumn{14}{|c|}{ Pseudomonas syringae pv. garcae } & \multicolumn{7}{|c|}{ Pseudomonas syringae pv. tabaci } \\
\hline & \multicolumn{3}{|r|}{$\mathbf{R}$} & \multicolumn{2}{|c|}{ MR } & \multicolumn{2}{|r|}{$\mathbf{s}$} & \multirow[b]{2}{*}{$\mathrm{n}=$} & \multicolumn{2}{|c|}{$\mathbf{R}$} & \multicolumn{2}{|c|}{ MR } & \multicolumn{2}{|r|}{ s } & \multicolumn{3}{|r|}{$\mathbf{R}$} & \multicolumn{2}{|c|}{ MR } & \multicolumn{2}{|r|}{$\mathbf{S}$} \\
\hline & $\mathrm{n}=$ & $\mathrm{n}^{\circ}$ & $\%$ & $n^{\circ}$ & $\%$ & $n^{\circ}$ & $\%$ & & $n^{\circ}$ & $\%$ & $n^{\circ}$ & $\%$ & $n^{\circ}$ & $\%$ & $\mathrm{n}=$ & $\mathrm{n}^{\circ}$ & $\%$ & $\mathrm{n}^{\circ}$ & $\%$ & $\mathrm{n}^{\circ}$ & $\%$ \\
\hline $\begin{array}{l}\text { Coffea arabica } \\
\text { cv. IAC } 125 \\
\text { RN }\end{array}$ & 12 & 0 & 0.0 & 0 & 0.0 & 12 & 100.0 & 17 & 0 & 0.0 & 0 & 0.0 & 17 & 100.0 & 6 & 0 & 0.0 & 0 & 0.0 & 6 & 100.0 \\
\hline $\begin{array}{l}\text { Coffea arabica } \\
\text { cv. IAC 376- } \\
4\end{array}$ & 9 & 0 & 0.0 & 0 & 0.0 & 9 & 100.0 & - & - & - & - & - & - & - & 3 & 0 & 0.0 & 0 & 0.0 & 3 & 100.0 \\
\hline $\begin{array}{l}\text { Coffea arabica } \\
\text { cV. IAC } 81\end{array}$ & 8 & 0 & 0.0 & 0 & 0.0 & 8 & 100.0 & - & - & - & - & - & - & - & 4 & 0 & 0.0 & 0 & 0.0 & 4 & 100.0 \\
\hline $\begin{array}{l}\text { Coffea } \\
\text { anthonyi }\end{array}$ & 3 & 0 & 0.0 & 0 & 0.0 & 3 & 100.0 & - & - & - & - & - & - & - & - & - & - & - & - & - & - \\
\hline $\begin{array}{l}\text { Coffea } \\
\text { congensis }\end{array}$ & - & - & - & - & - & - & - & 23 & 0 & 0.0 & 0 & 0.0 & 23 & 100.0 & - & - & - & - & - & - & - \\
\hline $\begin{array}{l}\text { Coffea } \\
\text { kapakata }\end{array}$ & 12 & 0 & 0.0 & 0 & 0.0 & 12 & 100.0 & 21 & 0 & 0.0 & 0 & 0.0 & 21 & 100.0 & 5 & 0 & 0.0 & 0 & 0.0 & 5 & 100.0 \\
\hline $\begin{array}{l}\text { Coffea } \\
\text { heterocalyx }\end{array}$ & 4 & 0 & 0.0 & 0 & 0.0 & 4 & 100.0 & - & - & - & - & - & - & - & - & - & - & - & - & - & - \\
\hline Coffea humilis & 12 & 0 & 0.0 & 1 & 8.4 & 11 & 91.6 & 2 & 0 & 0.0 & 0 & 0.0 & 2 & 100.0 & 5 & 0 & 0.0 & 0 & 0.0 & 5 & 100.0 \\
\hline $\begin{array}{l}\text { Coffea liberica } \\
\text { var. liberica }\end{array}$ & - & - & - & - & - & - & - & 16 & 1 & 6.3 & 5 & 31.2 & 10 & 62.5 & - & - & - & - & - & - & - \\
\hline $\begin{array}{l}\text { Coffea liberica } \\
\text { var. dewevrei }\end{array}$ & - & - & - & - & - & - & - & 19 & 2 & 10.5 & 0 & 0.0 & 17 & 89.5 & - & - & - & - & - & - & - \\
\hline $\begin{array}{l}\text { Coffea } \\
\text { liberica var. } \\
\text { passipagore }\end{array}$ & 10 & 0 & 0.0 & 3 & 30.0 & 7 & 70.0 & - & - & - & - & - & - & - & 3 & 0 & 0.0 & 0 & 0.0 & 3 & 100.0 \\
\hline $\begin{array}{l}\text { Coffea } \\
\text { congensis IAC } \\
4349\end{array}$ & 8 & 0 & 0.0 & 5 & 62.5 & 3 & 37.5 & 16 & 3 & 18.8 & 2 & 12.4 & 11 & 68.8 & 5 & 4 & 80.0 & 1 & 20.0 & 0 & 0.0 \\
\hline $\begin{array}{l}\text { Coffea } \\
\text { congensis IAC } \\
4350\end{array}$ & - & - & - & - & - & - & - & 20 & 8 & 40.0 & 3 & 15.0 & 9 & 45.0 & - & - & - & - & - & - & - \\
\hline $\begin{array}{l}\text { Coffea } \\
\text { canephora } \\
\text { var. robusta }\end{array}$ & 7 & 3 & 42.9 & 1 & 14.2 & 3 & 42.9 & - & - & - & - & - & - & - & 5 & 3 & 60.0 & 0 & 0.0 & 2 & 40.0 \\
\hline $\begin{array}{l}\text { Coffea } \\
\text { eugenioides }\end{array}$ & 11 & 2 & 18.2 & 6 & 54.5 & 3 & 27.3 & 19 & 8 & 42.1 & 1 & 5.3 & 10 & 52.6 & 5 & 1 & 20.0 & 0 & 0.0 & 4 & 80.0 \\
\hline $\begin{array}{l}\text { Coffea } \\
\text { stenophylla }\end{array}$ & 6 & 1 & 16.6 & 4 & 66.8 & 1 & 16.6 & - & - & - & - & - & - & - & 3 & 3 & 100.0 & 0 & 0.0 & 0 & 0.0 \\
\hline $\begin{array}{l}\text { Coffea } \\
\text { salvatrix }\end{array}$ & 11 & 4 & 36.4 & 4 & 36.4 & 3 & 27.2 & - & - & - & - & - & - & - & 4 & 3 & 75.0 & 0 & 0.0 & 1 & 25.0 \\
\hline
\end{tabular}

R: resistant, score $\mathrm{O}$ on the disease rating scale; MR: moderately resistant, 1 point on the disease rating scale; S: susceptible, with 2 to 5 points on the disease rating scale; -: not evaluated. 
Biológico - IBSBF). A preliminary study reported that mixed P. syringae pv. garcae strains induced high levels of disease severity (RODRIGUES et al., 2017a). A mixture of the P. syringae pv. garcae strains IBSBF 75 and IBSBF 1197, considered highly aggressive, was used to evaluate BHB severity. A 1:1 ratio mixture consisting of $2 \mathrm{~mL}$ of each bacterial suspension was inoculated. Pseudomonas syringae pv. tabaci strain IBSBF 2249 was used to evaluate the BLS resistance of the plants.

Bacterial suspensions for coffee seedling inoculations were standardized in a spectrophotometer for approximately $3 \times 10^{8}$ CFU.mL ${ }^{-1}$ (A $600 \mathrm{~nm}=0.3$ ) (LELLIOT; STEAD 1987). Inoculations were performed by the abrasion technique (RODRIGUES et al., 2017a).

\section{Experimentation}

The response of Coffea spp. to BHB was tested in two independent experiments, in 2012 (E1) and 2013 (E2), using 11 and seven species, respectively. The experiment was arranged in a completely randomized design with three to 23 replications per species, and the experimental plots consisted of a single plant. After inoculation, the plants were maintained at a relative humidity level above $70 \%$.
In 2014, the same coffee plants used in E1 were pruned and maintained at low relative humidity, unfavorable to pathogen growth. Subsequently, in 2015 (E3), plants with $4-5$ expanded leaves (approximately $5-6$ months after pruning) were tested against $P$. syringae pv. tabaci, strain IBSBF 2249.

In 2014 (E4), the behavior of 16 C. arabica accessions in response to $\mathrm{BHB}$ was evaluated as described above. After the end of the experimental period, 42 days after inoculation (DAI), the plants were pruned and maintained at low relative humidity, unfavorable to the pathogen. In 2015 (E5), after the development of at least three healthy internodes, the plants were tested for BLS-resistance. The experimental design was a completely randomized design with six replications per accession, and the plots represented by a single plant.

\section{Disease evaluation}

A 0 - 5-disease-rating scale was used, according to the symptoms observed in the inoculated area, in which 0 was attributed to symptom-free plants and 5 to leaves with necrosis of the entire inoculated area (RODRIGUES et al., 2017a). For the interpretation of results, the following classification

Table 2. Number of inoculated seedlings, frequency of resistance, moderately resistance and susceptible plants, according to the disease rating scale of $0-5$ points, 42 days after inoculation of germplasm, evaluated in relation to infection by Pseudomonas syringae pv. garcae and $P$. syringae pv. tabaci causal agents of bacterial halo blight and bacterial leaf spot, respectively.

\begin{tabular}{|c|c|c|c|c|c|c|c|c|c|c|c|c|c|c|}
\hline \multirow{3}{*}{ Germplasm } & \multicolumn{7}{|c|}{ Pseudomonas syringae pv. garcae (E4) } & \multicolumn{7}{|c|}{ Pseudomonas syringae pv. tabaci (E5) } \\
\hline & \multirow[b]{2}{*}{$n=$} & \multicolumn{2}{|c|}{$\mathbf{R}$} & \multicolumn{2}{|c|}{ MR } & \multicolumn{2}{|r|}{ S } & \multirow[b]{2}{*}{$\mathrm{n}=$} & \multicolumn{2}{|c|}{$\mathbf{R}$} & \multicolumn{2}{|c|}{ MR } & \multicolumn{2}{|c|}{ S } \\
\hline & & $n^{\circ}$ & $\%$ & $n^{\circ}$ & $\%$ & $n^{\circ}$ & $\%$ & & $n^{\circ}$ & $\%$ & $n^{\circ}$ & $\%$ & $n^{\circ}$ & $\%$ \\
\hline Coffea arabica var. Abyssinica & 6 & 0 & 0.0 & $\mathrm{O}$ & 0.0 & 6 & 100.0 & 6 & 0 & 0.0 & 0 & 0.0 & 6 & 100.0 \\
\hline Coffea arabica var. Crassinervia & 6 & 0 & 0.0 & 0 & 0.0 & 6 & 100.0 & 6 & 0 & 0.0 & 0 & 0.0 & 6 & 100.0 \\
\hline Coffea arabica var. Dilla \& Alghe & 6 & 2 & 33.3 & 1 & 16.7 & 3 & 50.0 & 6 & 0 & 0.0 & 1 & 16.7 & 5 & 83.3 \\
\hline Coffea arabica var. Glaucia & 6 & 0 & 0.0 & 0 & 0.0 & 6 & 100.0 & 6 & 0 & 0.0 & 0 & 0.0 & 6 & 100.0 \\
\hline Coffea arabica cv. Iarana & 6 & 0 & 0.0 & 0 & 0.0 & 6 & 100.0 & 6 & 0 & 0.0 & 0 & 0.0 & 6 & 100.0 \\
\hline Coffea arabica cv. Ibaare & 6 & 0 & 0.0 & 0 & 0.0 & 6 & 100.0 & 6 & 0 & 0.0 & 1 & 16.7 & 5 & 83.3 \\
\hline Coffea arabica cv. IPR 102 & 6 & 6 & 100.0 & 0 & 0.0 & 0 & 0.0 & 6 & 2 & 33.3 & 2 & 33.3 & 2 & 33.3 \\
\hline Coffea arabica cv. Ibairi & 6 & 0 & 0.0 & 0 & 0.0 & 6 & 100.0 & 6 & 0 & 0.0 & 0 & 0.0 & 6 & 100.0 \\
\hline C. arabica var. Pacas & 6 & 0 & 0.0 & 0 & 0.0 & 6 & 100.0 & 6 & 0 & 0.0 & 0 & 0.0 & 6 & 100.0 \\
\hline Coffea arabica var. Palido Viridis & 6 & 6 & 100.0 & 0 & 0.0 & 0 & 0.0 & 6 & 1 & 16.7 & 5 & 83.3 & 0 & 0.0 \\
\hline Coffea arabica var. Pendula & 6 & 0 & 0.0 & 0 & 0.0 & 6 & 100.0 & 6 & 0 & 0.0 & 0 & 0.0 & 6 & 100.0 \\
\hline Coffea arabica cv. São Bernardo & 5 & 2 & 40.0 & 0 & 0.0 & 3 & 60.0 & 5 & 0 & 0.0 & 0 & 0.0 & 6 & 100.0 \\
\hline São Bernardo × Mundo Novo & 6 & 0 & 0.0 & 0 & 0.0 & 6 & 100.0 & 6 & 0 & 0.0 & 0 & 0.0 & 6 & 100.0 \\
\hline Coffea arabica cv. Villa Lobos & 6 & 0 & 0.0 & 0 & 0.0 & 6 & 100.0 & 6 & 0 & 0.0 & 0 & 0.0 & 6 & 100.0 \\
\hline Coffea arabica cv. Villa Sarchi & 6 & 2 & 33.3 & 0 & 0.0 & 4 & 66.7 & 6 & 0 & 0.0 & 0 & 0.0 & 6 & 100.0 \\
\hline Coffea arabica cv. IAC $125 \mathrm{RN}$ & 6 & 0 & 0.0 & 0 & 0.0 & 6 & 100.0 & 6 & 0 & 0.0 & 0 & 0.0 & 6 & 100.0 \\
\hline
\end{tabular}

R: resistant, score $\mathrm{O}$ on the disease rating scale; MR: moderately resistant, 1 point on the disease rating scale; S: susceptible, with 2 to 5 points on the disease rating scale. 
was considered: resistant (score 0); moderately resistant (1); and susceptible ( 2 to 5 points on the disease-rating scale).

\section{RESULTS}

The results of the experiments E1 and E2 are shown in Table 1. In the cultivars Coffea arabica Mundo Novo IAC 376-4 and Catuaí Vermelho IAC 81, high susceptibility levels to P. syringae pv. garcae were observed in E1, similar to cultivar IAC $125 \mathrm{RN}$, used as susceptible control. Susceptibility of all plants of the species C. kapakata A. Chev., C. anthonyi Stoff. \& F. Anthony, and $C$. heterocalyx Stoff. was also observed. However, over the experimental period, disease evolution varied among the plants of each species, unlike in the case of the $C$. arabica cultivars, with a generally uniform development. The disease evolution in susceptible plants was heterogeneous, varying among the plants of each species, especially in $C$. anthonyi and $C$. heterocalyx.

In C. kapakata, between 7 and 21 DAI, all inoculated leaves dropped, and, in some cases, the bacteria colonized young leaves in the expansion phase.

Segregation for $\mathrm{BHB}$ resistance in variable proportions was observed in the other seven evaluated Coffea species (Table 1).

While high percentages of BHB-susceptible plants were found in progenies of $C$. humilis A. Chev. (91.6\%) and $C$. liberica var. passipagore (70\%), 42.9 and $37.5 \%$, respectively, were found for $C$. canephora and C. congensis A. Froehner IAC 4,349. Lowest percentages of susceptible plants were observed in C. salvatrix Swynn \& Phillipson (27.2\%), C. eugenioides (27.3\%) and C. stenophylla (16.6\%).

In BHB-resistant plants, distinct reactions were observed in leaf tissues around the wounds caused by inoculations. The species $C$. salvatrix and $C$. canephora showed no visible changes around the inoculation areas. In some resistant plants of C. eugenioides and C. stenophylla, darkening around the injured points was observed. Additionally, around some wounds, the presence of a yellowish halo without visual signs of pathogen colonization was observed (Fig. 1). Bacterial flow exudates from these tissues tested negative for the pathogen.

Similar results were obtained in E2 (Table 1). Lowest percentages of susceptible coffee trees were found for $C$. congensis IAC 4,350 (45\%) and C. eugenioides (52.6\%), and the highest percentage of resistant coffee trees (42.1\%) (Table 1).

All plants of the species C. kapakata and C. humilis were susceptible, as well as those of the susceptible control cultivar IAC $125 \mathrm{RN}$ of $C$. arabica.

Segregation for BHB resistance was observed in progenies of other species. The frequency of resistant plants was about $40 \%$ in progenies of $C$. eugenioides and C. congensis IAC 4,350 and less than $20 \%$ in $C$. liberica var. liberica, C. liberica var. dewevrei, and $C$. congensis. In these three species, the percentage of susceptible plants was $62.5,89.5$ and $68.8 \%$, respectively.

The symptom development in E2 plants was similar as in those of the previous tests (E1). The severity in C. kapakata peaked seven DAI, while symptom evolution was slower on plants of the susceptible cultivar IAC $125 \mathrm{RN}$.

The severity of BLS was also evaluated in nine species of the genus Coffea (E3). Results of the plants of each progeny were ranked according to the level of disease resistance/susceptibility (Table 1 ).

The species $C$. humilis, C. kapakata and C. liberica var. passipagore were found to be as susceptible to P. syringae pv. tabaci as the evaluated $C$. arabica cultivars.

Sources of BLS-resistance were observed in the species C. congensis, cultivar IAC 4,349, C. canephora, C. eugenioides, C. stenophylla, and C. salvatrix. Among these, only C. congensis and $C$. stenophylla had no BLS-susceptible plants. In resistant coffee trees of C. stenophylla and in only one of C. salvatrix, dry lesions surrounded by a discrete yellow halo, with no visual symptoms of bacteria colonization, were observed $42 \mathrm{DAI}$
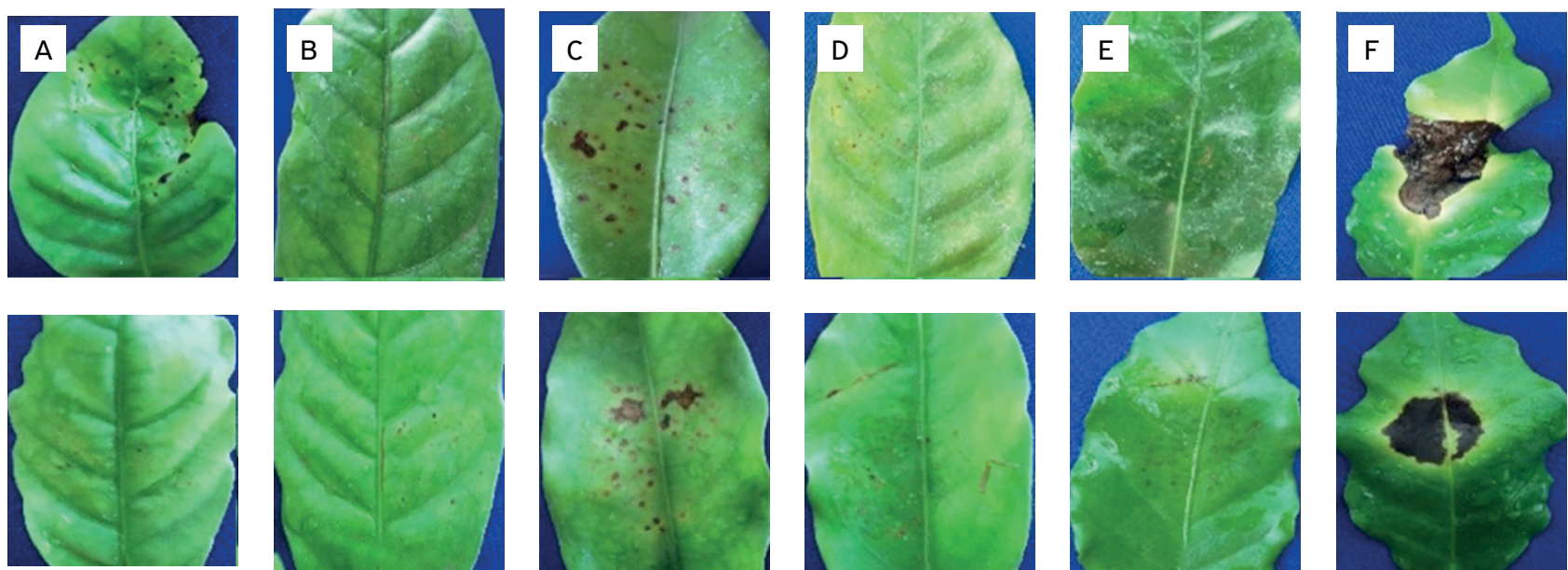

Figure 1. Reaction of Coffea spp. against Pseudomonas syringae pv. garcae (pictures above) and $P$. syringae pv. tabaci (pictures below), respectively in: (A) Coffea canephora; (B) C. congensis; (C) C. eugenioides; (D) C. stenophylla; (E) C. salvatrix; (F) C. arabica, cultivar cultivar IAC 125 RN (F), 42 days after inoculation. 
(Fig. 1). Microscopic examinations of bacterial flow exudates tested negative.

The analysis of the reactions of the evaluated cultivars and botanical and exotic varieties of $C$. arabica to $P$. syringae, pathovars garcae (E4) and tabaci (E5), are shown in Table 2. All plants of cultivar IPR 102, as well as the variety Palido Viridis, were BHB-resistant. However, resistance to P. syringae pv. tabaci was only observed in Palido Viridis, classified as resistant (1) or moderately resistant (5). The plants of cultivar IPR 102 were BLS-susceptible.

Genetic variability for simultaneous resistance to $P$. syringae pathovars garcae and tabaci was identified in progenies of variety Dilla \& Alghe. Of the varieties São Bernardo and Villa Sarchi, 40 and 33.3\% were BHB-resistant, respectively, although BLS-susceptible. All other evaluated C. arabica genotypes were susceptible to both diseases.

\section{DISCUSSION}

Resistance to BHB was reported previously by MOHAN et al. (1978) in the species $C$. eugenioides and $C$. stenophylla. Our results extended the diversity of resistance sources with the inclusion of $C$. liberica, C. canephora, C. congensis, and $C$. salvatrix. Sources of simultaneous resistance to the pathovars $P$. syringae garcae and tabaci were identified in the species $C$. canephora, $C$. congensis, $C$. eugenioides, $C$. salvatrix, and C. stenophylla.

In the studied plant species, resistance reactions to P. syringae pv. garcae and P. syringae pv. tabaci occur separately or simultaneously, suggesting the existence of different genes acting in the resistance expression to both pathovars in coffee plants. Probably, there are different resistance mechanisms against these pathogens in the analyzed populations.

Different Coffea species, resistant to BHB and/or BLS, have a particular use in phytobacteriology, with a view to identify infraspecific variability of these pathogens, as already known for other pathovars of $P$. syringae. The transfer of the resistance genes contained in these resistant sources may also allow the development of a cultivar with intrinsic traits found only in these species.

In spite of some difficulties of this strategy, e.g., the existence of genetic barriers to interspecific crosses (CARVALHO; MONACO, 1968) and the long time required for the introgression of genes of interest and recovery of the recurrent genome, a $C$. arabica cultivar resistant to $L$. coffeella was developed in Brazil, by the transfer of resistance genes from C. racemosa (CARDOSO et al., 2014; MENDONÇA et al., 2016). Low-caffeine content cultivars were selected by hybridization of $C$. eugenioides in recombination with the species C. arabica and C. canephora (NAGAI et al., 2008).
Other currently available methods, e.g., marker-assisted selection (BERNARDO, 2008) or genome-wide selection (MEUWISSEN et al., 2001), can make the use of wild species with multiple traits of interest feasible, for example of $C$. eugenioides and $C$. salvatrix, according to our studies both resistant to bacterial diseases, resistant to leaf-miner (GUERREIRO FILHO et al., 1991) and having a low caffeine content in the endosperm (MAZZAFERA; CARVALHO, 1992). Coffea eugenioides was also resistant to coffee berry borer, Hypothenemus hampei Ferrari (SERA et al., 2010), and in C. salvatrix the seed oil content was high (MAZZAFERA et al., 1998).

Genome-wide selection was used by ALKIMIM et al. (2017) for the identification and selection of C. arabica genotypes carrying resistant genes to leaf rust and coffee berry disease, caused by Colletotrichum kahawae (Waller \& Bridge), introgressed from $C$. liberica and $C$. canephora, respectively. The profile of the species $C$. liberica was remarkable for Arabica coffee breeding, for having plants that carry the $\mathrm{S}_{\mathrm{H}} 3$ gene, a resistant source to all Hemileia vastatrix races described in Brazil so far (FAZUOLI et al., 2009), being indicated as tolerant to cold stress (PETEK et al., 2005; FORTUNATO et al., 2010), as well as having simultaneous BHB and BLS resistance, according to our results.

Among the diploid species, C. canephora was the most adequate BHB and BLS-resistance source for traditional C. arabica breeding, since hybrids between these species could be established without difficulty (CARVALHO et al., 1984), and the simultaneous resistance to these pathogens was observed in this study at a relatively high frequency in progenies of this species. The proportion of BHB-resistant (43\%) and BLSresistant $(60 \%)$ coffee trees in the evaluated progenies suggests that the frequency of resistance alleles in the tested genotype C. canephora is high. Several C. arabica cultivars have been developed from interspecific hybridizations of $C$. canephora with leaf rust resistant genes, such as Icatu (Brazil) (FAZUOLI et al., 1983), Ruiru 11 (Kenya) (OMONDI et al., 2001), and Cenicafé 1 (Colombia) (FLÓREZ et al., 2016).

However, a detailed investigation of resistance in C. canephora is required, since plants of this species evaluated by COSTA et al. (1957) and MOHAN et al. (1978) were BHB-susceptible. These divergent results suggest considerable variability in the disease resistance of this species.

In view of the difficulties described above, the most adequate method to breed new cultivars with simultaneous and stable resistance is the exploration of a primary gene pool of C. arabica accessions identified as BHB and BLS-resistant.

In this context, the most promising genetic material of the evaluated germplasms is cultivar IPR 102, which is highly yielding and segregates only genes for BLS resistance. This cultivar resulted from the hybridization between $C$. arabica Bourbon Vermelho Co 667 and C. canephora var. Robusta Co 254. Therefore, the resistance to both pathogens is probably the result of introgression of resistance genes contained in 
C. canephora. The BHB-susceptibility of cultivar Bourbon Vermelho (RODRIGUES et al., 2017a) and the frequency of resistant plants of C. canephora to the pathovars garcae and tabaci recorded in this study support this hypothesis.

The inoculation results of $C$. arabica variety Villa Sarchi agreed with MORAES et al. (1975) and confirmed the resistance to BHB. The mutant Palido Viridis of $C$. arabica, less productive but $\mathrm{BHB}$ and BLS-resistant, is also an important tool for studies related to resistance inheritance and for coffee breeding programs. A few plants of $C$. arabica, variety São Bernardo, were BHB-resistant, probably due to exogenous pollen grain fertilization, since no plants of the hybrid São Bernardo $\times$ Mundo Novo with resistance to the disease were observed.

Although the pathogens are genetically very similar, the presence of resistance to one pathogen in a plant does not mean resistance to the other. Therefore, further studies aiming at the selection of plants with multiple resistance to these agents are highly desirable, as well as an improved knowledge of the resistance mechanisms involved.

\section{ACKNOWLEDGEMENTS}

This study was financed in part by the Coordenaçáo de Aperfeiçoamento de Pessoal de Nível Superior - Brasil (CAPES) - Finance Code 001. The authors are grateful to the National Council for Scientific and Technological Development (Conselho Nacional de Desenvolvimento Científico e Tecnológico - CNPq) for a research fellowship (OGF CNPq DT 308.634/2016-0 and SALD CNPq DT $30.31 .22 / 2017-0$ ) and the financial support (grant CNPq 479.589/2013-5).

\section{REFERENCES}

ALKIMIM, E.R.; CAIXETA, E.T.; SOUSA, T.V.; PEREIRA, A.A.; OLIVEIRA, A.C.B.; ZAMBOLIM, L.; SAKIYAMA, N.S. Marker-assisted selection provides arabica coffee with genes from other Coffea species targeting on multiple resistance to rust and coffee berry disease. Molecular Breeding, Springer Netherlands, v.37, n.6, 2017. https://doi.org/10.1007/s1 1032-016-0609-1

ALMEIDA, I.M.G.; MACIEL, K.W.; BERIAM, L.O.S.; RODRIGUES, L.M.R.; DESTÉFANO, S.A.L.; RODRIGUES NETO, J.; PATRÍCIO, F.R.A. Increase in incidence of bacterial halo blight (Pseudomonas syringae pv. garcae), in coffee producing areas in Brazil. In: INTERNATIONAL CONFERENCE ON COFFEE SCIENCE, 24., San José. Proceedings... San José: ASIC, 2012. p.1080-1084.

AMARAL, J.F.; TEIXEIRA, C.G.; PINHEIRO, E.D. O bactério causador da mancha aureolada do cafeeiro. Arquivos do Instituto Biológico, São Paulo, v.23, p.151-155, 1956.

BERNARDO, R. Molecular markers and selection for complex traits in plants: learning from the last 20 years. Crop Science, v.48, n.5, p.1649-1664, 2008. 10.2135/cropsci2008.03.0131

BETTENCOURT, A.J.; CARVALHO, A. Melhoramento visando à resistência do cafeeiro à ferrugem. Bragantia, Campinas, v.27, n. 1, p.35-68, 1968. http://dx.doi.org/10.1590/S0006-87051968000100004

BRADBURY, J.F. Guide to plant pathogenic bacteria. Farhan House: C.A.B. International, 1986.

CARDOSO, D.C.; MARTINATI, J.C.; GIACHETTO, P.F.; VIDAL, R.O.; CARAZZOLLE, M.F.; PADILHA, L.; GUERREIRO FILHO, O.; MALUF, M.P. Large-scale analysis of differential gene expression in coffee genotypes resistant and susceptible to leaf miner-toward the identification of candidate genes for marker assisted-selection. BMC Genomics, v. 15, p. 1-20, 2014. https://doi.org/10.1 186/1471-2164-15-66
CARVALHO, A.; MONACO, L.C. Relaciones geneticas de especies selecionadas de Coffea. Cafe, Lima, v.9, n.4, p. 1-19, 1968.

CARVALHO, A.; MEDINA FILHO, H.P.; FAZUOLI, L.C. Evolução e melhoramento do cafeeiro. In: I Colóquio sobre citogenética e evolução de plantas, 1984. Piracicaba, SP. Tópicos de Citogenética e Evolução de Plantas. Sociedade Brasileira de Genética, São Paulo, v.21, p.215-234, 1984.

COSTA, A.S.; AMARAL, J.F.; VIEGAS, A.P.; SILVA, D.M.; TEIXEIRA, C.G.; PINHEIRO, E.D. Bacterial halo blight of coffee in Brazil. Phytopathologische Zeitschrift, Berlin, v.28, p.427-444, 1957.

DAVIS, A.P.; GOVAERTS, R.; BRIDSON, D.M.; STOFFELEN, P. An annotated taxonomic conspectus of the genus Coffea (Rubiaceae). Botanical Journal of the Linnean Society, United Kingdom, v.152, n.4, p.465-512, 2006. https://doi. org/10.1111/j.1095-8339.2006.00584.x

DESTÉFANO, S.A.L.; RODRIGUES, L.M.R.; BERIAM, L.O.S.; PATRÍCIO, F.R.A.; THOMAZIELLO, R.A.; RODRIGUES NETO, J. Bacterial leaf spot caused by Pseudomonas syringae pv. tabaci in Brazil. New Disease Reports, London, v.22, n.5, 2010.

FOOD AND AGRICULTURE ORGANIZATION OF THE UNITED NATIONS (FAO). Coffee mission to Ethiopia 1946 - 1965 (1968). Rome, Italy: FAO, 1968. 200p. (Report, FAO.)

FAZUOLI, L.C.; CARVALHO, A.; COSTA, W.M.; NERY, C.; LAUN, C.R.P.; SANTIAGO, M. Avaliação de progênies e seleção no cafeeiro Icatu. Bragantia, Campinas, v.42, n.1, p.179-189, 1983. http://dx.doi.org/10.1590/ So006-87051983000100016 
FAZUOLI, L.C.; BRAGHINI, M.T.; SILVAROLLA, M.B.; MISTRO, J.C.; PATRÍCIO, F.R.A. Melhoramento do cafeeiro visando à resistência a doenças. IX Curso de Atualização em Café. Documentos IAC, Campinas, v.91, p.1-16, 2009.

FLÓREZ, R.C.P.; MALDONADO, L.C.E.; CORTINA, G.H.A.; MONCADA, B.M.P.; MONTOYA, R.E.C.; IBARRA, R.L.N.; UNIGARRO, M.C.A.; RENDÓN, S.J.R.; DUQUE, O.H. Cenicafé 1: Nueva variedad de porte bajo, altamente productiva, resistente a la roya y al CBD, con mayor calidad física del grano. Avances Técnicos Cenicafé, Colombia, v.469, 8p, 2016.

FORTUNATO, A.S.; LIDON, F.C.; BATISTA-SANTOS, P.; LEITÃO, A.E.; PAIS, I.P.; RIBEIRO, A.I.; RAMALHO, J.C. Biochemical and molecular characterization of the antioxidative system of Coffea sp. under cold conditions in genotypes with contrasting tolerance. Journal of Plant Physiology, v.167, n.5, p.333-342, 2010. https://doi. org/10.1016/j.jplph.2009.10.013

GUERREIRO FILHO, O. Cafeeiros resistentes ao bicho-mineiro. O Agronômico, Campinas, v.59, n. 1, p.47, 2007.

GUERREIRO FILHO, O.; MEDINA FILHO, H.P.; CARVALHO, A. Fontes de resistência ao bicho mineiro, Perileucoptera coffeella em Coffea spp. Bragantia, Campinas, v.50, n. 1, p.45-55, 1991. http://dx.doi.org/10.1590/S0006-87051991000100006

KAIRU, M.G. Biochemical and pathogenic differences between Kenyan and Brazilian isolates of Pseudomonas syringae pv. garcae. In: RUDOLPH K.; BURR T.J.; MANSFIELD J.W.; STEAD D.; VIVIAN A.; VON KIETZELL J. (orgs.). Pseudomonas Syringae Pathovars and Related Pathogens. Developments in Plant Pathology. Dordrecht: Springer, 1997. v.46. p.239-246.

KIMURA, O.; ROBBS, C.F.; RIBEIRO, R.L.D. Estudos sobre o agente da "Mancha aureolada do cafeeiro" (Pseudomonas garcae Amaral et al.). Arquivos da Universidade Federal Rural, Itaguaí, v.3. n.2, p. 15-18, 1973.

KOROBKO, A.; WONDINAGEGNE, E. Bacterial blight of coffee (Pseudomonas syringae pv. garcae) in Ethiopia. In: RUDOLPH, K.; BURR, T.J.; MANSFIELD, J.W.; STEAD, D.; VIVIAN, A.; VON KIETZELE, J. Pseudomonas syringae and related pathogens. Dordrecht: Springer, 1997. p.538-541. https://doi. org/10.1007/978-94-011-5472-7

KRISHNAN, S.; RANKER, T.A.; DAVIS, A.P.; RAKOTOMALALA, J.J. Current status of coffee genetic resources: implications for conservation - case study in Madagascar. Acta Horticulturae, v.101, p.15-19, 2015 . https://doi.org/10.17660/ ActaHortic.2015.1101.3

LELLIOTT, R.A.; STEAD, D.E. Methods for the diagnosis of bacterial diseases of plants. Oxford, UK: Blackwell Scientific Publications, 1987. (Methods in Plant Pathology. v.2.)

MALAVOLTA JÚNIOR, V.A.; BERIAM, L.O.S.; ALMEIDA, I.M.G.; RODRIGUES NETO, J.; ROBBS, C.F. Bactérias fitopatogênicas assinaladas no Brasil: uma atualização. Summa Phytopathologica, Botucatu, v.34 (supl.esp.), p.1-88, 2008.

MAZZAFERA, P.; CARVALHO, A. Breeding for low seed caffeine content of coffee (Coffea L.) by interspecific hybridization. Euphytica, Wageningen, v.59, n.1, p.55-60, 1992.
MAZZAFERA, P.; SOAVE, D.; ZULLO, M.A.T.; GUERREIRO FILHO, O. Oil content of green beans from some coffee species. Bragantia, Campinas, v.57, n.1, p.45-48, 1998. http://dx.doi.org/10.1590/ s0006-87051998000100006

MENDONÇA, A.P.; NONATO, J.V.A.; ANDRADE, V.T.; FATOBENE, B.J.R.; BRAGHINI, M.T.; PRELA-PANTANO, A.; GUERREIRO FILHO, O. Coffea arabica clones resistant to coffee leaf miner. Crop Breeding and Applied Biotechnology, Viçosa, v. 16, n. 1, p.42-47, 2016. http://dx.doi.org/10.1590/1984-70332016v16n 1 a7

MEUWISSEN, T.H.; HAYES, B.J.; GODDARD, M.E. Prediction of total genetic value using genome-wide dense marker maps. Genetics, v.157, n.4, p.1819-1829, 2001.

MOHAN, S.K.; CARDOSO, R.M.L.; PAIVA, M.A. Resistência em germoplasma de Coffea ao crestamento bacteriano incitado por Pseudomonas garcae Amaral et al. Pesquisa Agropecuária Brasileira, Brasília, v.13, n. 1, p.53-64, 1978.

MORAES, S.A.; SUGIMORI, M.H.; TOMAZELLO FILHO, M.; CARVALHO, P.C.T. Resistência de cafeeiros a Pseudomonas garcae. Summa Phytopathologica, Botucatu, v.1, p.105-110, 1975.

NAGAI, C.; RAKOTOMALALA, J.J.; KATAHIRA, R.; LI, Y.; YAMAGATA, K.; ASHIHARA, H. Production of a new low-caffeine hybrid coffee and the biochemical mechanism of low caffeine accumulation. Euphytica, Wageningen, v.164, n.1, p.133-142, 2008. https:// doi.org/10.1007/s 10681-008-9674-9

OMONDI, C.O.; AYIECHO, P.O.; MWANG'OMBE, A.W.; HINDORF, H. Resistance of Coffea arabica cv. Ruiru 11 tested with different isolates of Colletotrichum kahawae, the causal agent of coffee berry disease. Euphytica, Wageningen, v.121, n.1, p.19-24, 2001. https://doi.org/10.1023/A:1012056622969

PETEK, M.R.; SERA, T.; ALTEIA, M.Z. Selection for frost resistance in Coffea arabica progenies carrying $C$. liberica var. dewevrei genes. Crop Breeding and Applied Biotechnology, Viçosa, v.5, p.355-362, 2005. https://doi.org/10.12702/1984-7033.v05n03a14

RAMOS, A.H.; SHAVDIA, L.D. A dieback of coffee in Kenya. Plant Disease Reporter, St. Paul, v.60, n.10, p.831-835, 1976.

RODRIGUES, L.M.R.; RODRIGUES NETO, J.; PIERI, C.; THOMAZIELLO, R.A.; MARINGONI, A.C. Reação de genótipos de cafeeiro à mancha bacteriana causada por Pseudomonas syringae pv. tabaci. In: CONGRESSO PAULISTA DE FITOPATOLOGIA, 32., São Pedro, Resumos... CD ROM, 2009.

RODRIGUES, L.M.R.; ALMEIDA, I.M.G.; PATRÍCIO, F.R.A.; BERIAM, L.O.S.; MACIEL, K.W.; BRAGHINI, M.T.; GUERREIRO FILHO, O. Aggressiveness of strains and inoculation methods for resistance assessment to bacterial halo blight on coffee seedlings. Journal of Phytopathology, Berlin, v.165, n.2, p.105-114, 2017a. https:// doi.org/10.1111/jph.12543

RODRIGUES, L.M.R.; SERA, G.H.; GUERREIRO FILHO, O.; BERIAM, L.O.S.; ALMEIDA, I.M.G. First report of mixed infection by Pseudomonas syringae pathovars garcae and tabaci on coffee plantations. Bragantia, Campinas, v.76, n.4, p.543-549, 2017 b. http://dx.doi.org/10.1590/1678-4499.2016.399 
SERA, G.H.; SERA, T.; ITO, D.S.; RIBEIRO FILHO, C.; VILLACORTA, A.; KANAYAMA, F.S. Coffee berry borer resistance in coffee genotypes. BrazilianArchives of Biology and Technology, Curitiba, v.53,n.2,p.261-268, 2010.http://dx.doi.org/10.1590/S1516-89132010000200003

SERA, G.H.; SERA, T.; FAZUOLI, L.C. IPR 102 - Dwarf Arabica coffee cultivar with resistance to bacterial halo blight. Crop Breeding and Applied Biotechnology, Viçosa, v. 17, n.4, p.403-407, 2017. http://dx.doi.org/10.1590/1984-70332017v17n4c60

UNITED STATES DEPARTMENT OF AGRICULTURE (USDA). Coffee: world markets and trade. Washington, D.C.: USDA, 2014. 9p.

WOLF, F.A.; FOSTER, A.C. Bacterial leaf spot of tobacco. Science, v.47, 1189, p.361-362, 1917. https://doi.org/10.1126/ science.46.1189.361
YOUNG, J.M.; DYE, D.W.; BRADBURY, J.F.; PANAGOPOULOS, C.G.; ROBBS, C.F. A proposed nomenclature and classification for plant pathogenic bacteria. New Zealand Journal of Agricultural Research, Auckland, v.21, n.1, p.153-177, 1978. https://doi. org/10.1080/00288233.1978.10427397

XUEHUI, B.; LIHONG, Z.; YONGLIANG, H.; GUANGHAI, J.; JINHONG, L.; ZHANG, $H$. Isolation and identification of the pathogen of coffee bacterial blight disease. Chinese Journal of Tropical Crops, v.34, n.4, p.738-742, 2013.

ZOCCOLI, D.M.; TAKATSU, A.; UESUGI, C.H. Ocorrência de mancha-aureolada em cafeeiros na região do Triângulo Mineiro e Alto Paranaíba. Bragantia, Campinas, v.70, n.4, p.843-849, 2011 . http://dx.doi.org/10.1590/ so006-87052011000400017 